The College of Cardinals and the Veto

\author{
By \\ Henry Bradford Washburn
}





\section{THE COLLEGE OF CARDINALS AND THE VETO}

By Henry Bradford Washburn, Professor of Ecclesiastical History in the EPISCOPAL Theological School at Cambridge

\section{(Read December 30, 1913)}

$A^{T}$ the end of an article on State Interference in Papal that there might be a "new Papal Constitution affirming in explicit terms the absolute independence of conclaves" from the form of secular interference known as the Veto or Right of Exclusion. The article was written after the elevation of Pius $\mathrm{X}$, but before the publication of the Constitution Commissum Nobis. The latter was issued on January 20, 1904, and meets with gratifying precision the wishes of Father Thurston.

The Constitution Commissum Nobis is a brief document, devoted entirely to the Veto. Its important paragraphs read as follows:

The aforesaid civil Veto . . . by which the effort is made to prevent the advancement of a certain person to the supreme pontificate, is in opposition to (this) perfect freedom in electing to the Supreme Pontificate. Although it has occurred several times it has never been sanctioned by the Apostolic Chair. On the contrary, the Roman Pontiffs who have issued constitutions in regard to the things pertaining to the holding of a conclave have attempted nothing with more effort and zeal than the prohibition of interference of any external power whatsoever

×The Month, October, I903. 


\section{I58 The College of Cardinals and the Veto}

in a sacred Congregation of the Cardinals summoned to elect a Pope. The following Constitutions state the case clearly. In eligendis of Pius IV; Aterni Patris of Gregory XV; Apostolatus officium of Clement XII; especially In hac sublimi, Licet per Apostolicas, and Consulturi of Pius IX. Furthermore, since experience has taught that utterances intended to prevent the civil Veto or Exclusion have not coincided thus with the prayers, and because recent changes have made the interference of the civil power all the more destitute of reason and equity, therefore, We, by virtue of the Apostolic gift committed unto us, walking in the footsteps of Our predecessors, having given the matter due thought, with certain knowledge, and of Our own impulse, wholly condemn the civil Veto, or Exclusion, as it is called, even in the form of expressed desire, likewise every kind of intervention and every intercession of any nature, expressly declaring that it is unlawful for any one, especially for the supreme governors of states, to interpose or interfere, on any pretext whatsoever, in the weighty business of electing a Roman Pontiff. ${ }^{x}$

The Constitution is a reminiscence, as those who followed the details of the conclave of $1903 \mathrm{know}$, of circumstances which possibly led to the defeat of Cardinal Rampolla and to the election of Pius $\mathrm{X}$. A few days before the opening of the conclave the Cardinal-Bishop of Cracow had arrived at Rome evidently in possession of disagreeable news, and charged with a commission that would allow him no peace. To those who perceived his state of mind he confided that he was instructed to give the Exclusion to a certain candidate. He tried in vain to persuade others to publish his message. The secretary of the conclave answered that he could not; the cardinal-dean that he would not. Finally he went to Cardinal Rampolla himself, who told him to act as his conscience directed. And then at the beginning of the scrutiny, while the cardinals were writing their ballots, the CardinalBishop of Cracow asked permission to speak, and expressed himself literally as follows:

- Translated from the Latin text, which is reprinted in Die geltenden Papstwahlgesetze, ed. Giese, p. 36. 


\section{The College of Cardinals and the Veto 159}

I have the honor, having been summoned to the duty by an order from the highest source, to beg of your eminence, in his capacity as Dean of the Sacred College and Chamberlain of the Holy Roman Church, that he will take due notice and that he will announce and declare in the most official manner, in the name and by the authority, of his Apostolic Majesty, Francis Joseph, Emperor of Austria and King of Hungary, who desires to take advantage of an ancient right and privilege, the veto of Exclusion against my most eminent Lord and Cardinal Mariano Rampolla del Tindaro.

Upon hearing the announcement the cardinal-dean said that the conclave would not receive the communication. Cardinal Rampolla arose and said:

I regret that a lay power has caused a serious infringement of the liberty of the Church and of the dignity of the sacred college in the election of a pope, and I therefore protest most earnestly. As for myself, I assert that nothing more honorable, nothing of more fortunate character, could happen to me. ${ }^{x}$

One who witnessed the incident ${ }^{2}$ reports that the interference of Austria was looked upon as an offensive anachronism and that Austria not only had to see the final election of a pope from hated Venice but that its Veto was of no effect. In regard to the latter point, as the election proceeded Rampolla's vote at once increased, as if in defiance of Austria, but by one vote only. Rampolla was not elected, possibly because he never would have been, possibly because of the Veto.

Pius $X$, therefore, was indulging in reminiscence when he published the Constitution Commissum Nobis. He was also protesting against the recurrence of even an inoperative Veto. He was declaring that, whatever the custom had been, states should take neither direct nor indirect part in future elections. He was also playing the rôle of prophet.

× Revue des Deux Mondes, t. xx, 1904, p. 280.

Ibid., pp. 280 sq. 


\section{The College of Cardinals and the Veto}

He was forecasting the day when the College of Cardinals would realize the ambition of centuries that the Church should be utterly free from the State.

In taking this attitude, however, was not Pius making a new departure? And in its apparent contempt of the Veto was not the conclave of 1903 opening anothey chapter of policy? If the Veto was actually repudiated in 1903 was it not for the first time?

The Veto was either threatened or exercised in practically every conclave of the nineteenth century excepting those of Pius IX and Leo XIII. It is said on reliable authority that the Veto would have been given Pius IX had not the election taken place so speedily that the Austrian crown cardinal, armed with an Exclusion, had not time to arrive before the ballot. It is also said that fear of a Veto was the cause of the unusual haste. However this may be, a change had come over the electors between the time when, in 1830 , Giustiniani had been excluded by Spain and when Rampolla was excluded in 1903 by Austria. For in Giustiniani's case there was an apparent recognition of the Spanish right of interference. As the Exclusion is one of the most dramatic in history, a repetition of its details may not be amiss. They are given by Cardinal Wiseman, who was a student in Rome at the time.

On the 7 th of January (1830) Cardinal Giustiniani received twenty-one votes, the number sufficient for election being twenty-nine, when Cardinal Marco, Spanish envoy delicately intimated, first to Giustiniani's nephew, Odescalchi, then to the Dean Pacca, that Spain objected to that nomination. Every one was amazed. Giustiniani had been nuncio in Spain; and the ground for his exclusion was supposed to be his participation in Leo XII's appointment of bishops in South America. . . . Every one in that conclave, however, bore witness to the admirable conduct of that excellent and noble prince on that occasion. I have heard Cardinal Weld, and his secretary in conclave, Bishop Riddell, describe how wretched and pining he looked while the 


\section{The College of Cardinals and the Veto $\mathbf{1 6 \mathbf { I }}$}

prospect of the papacy hung before him, for he was scrupulous and tender of conscience to excess; and how he brightened up and looked himself again, the moment the vision had passed away. Indeed, no sooner had the note of the Spanish lay ambassador, Labrador, been read in his presence by the Dean, than Cardinal Giustiniani arose, and standing in the middle of the chapel, addressed his colleagues. . . . With an unfaltering voice, and a natural tone, unagitated by his trying position, the Cardinal said: "If I did not know courts by experience, I should certainly have cause to be surprised at the 'exclusion' published by the most eminent Dean; since far from being able to reproach myself with having given cause of complaint against me to his Catholic Majesty during my nunciature, I dare congratulate myself with having rendered his Majesty signal service in the difficult circumstances wherein he was placed." He then referred to some proofs of acknowledgment of this fidelity from the Spanish Crown and continued: "I will always cherish these kindnesses shown me by his Catholic Majesty, and will entertain toward him the most profound respect, and in addition a most lively interest for all that can regard his welfare, and that of his august family. I will further add, that, of all the benefits conferred on me by his Majesty, I consider the greatest and most acceptable to me (at least in its effects) to be his having this day closed for me the access to the most sublime dignity of the Pontificate. Knowing as I do my great weakness, I could not bring myself to foresee that I should ever have to take on myself so heavy a burden; yet these few days back, on seeing that I was thought of for this purpose, my mind has been filled with the bitterest sorrow. Today I find myself free from all anxiety, I am restored to tranquillity, and I retain only the gratification of knowing that some of my most worthy colleagues have deigned to cast a look on me, and have honored me with their votes, for which I beg to offer them my eternal and sincerest gratitude."x

Of even more interest than Giustiniani's words are the results of the Spanish Exclusion. On the two following scrutinies Giustiniani received respectively ten and two ballots. And of even more interest than the immediate

I Wiseman, Recollections of the Last Four Popes, pp. 264 sq. 
effect of the Exclusion is the fact that Wiseman assumes that Spain was justified in its conduct and that the Roman Catholic scholar, Herbert Thurston, gives to Wiseman unquestioned assent. ${ }^{3}$ In other words, the spirit that prevailed in the conclave of 1830 was of a radically different kind from that in the conclave of 1903. Both from conduct and from papal Constitution the conclave of 1903 may mark an epoch in the history of the College of Cardinals.

Inasmuch as the procedure of 1830 is typical of the conclaves of the nineteenth century, wherein the Exclusion was given, and of most of those of the eighteenth century, to discover the moment of another significant change we are thrust back into the early days of the eighteenth century. Ludwig Wahrmund, one of the leading canon lawyers of Romanism, and one of the three or four scholars who have given special attention to the history of the conclave, published in 1912 the diary of Cardinal Francesco Barberini. ${ }^{2}$ Barberini was a member of the electing college of $\mathbf{1 7 2 I}$. His diary gives a detailed account of the exclusion of Cardinal Paolucci and of the election of Innocent XIII. Whereas the method of election preceding the pontificate of Innocent XIII was different from that of the conclave in which he himself was chosen pope, events within the latter are naturally of importance. They mark the close of a transition period-a period in which the Exclusion changed from an informal privilege to a formal right. The conduct of the Imperial Cardinal Althann reveals signs of distinct novelty.

In brief the account of Barberini is as follows: When Althann saw that Paolucci had received within a few votes of the necessary two-thirds, he rose from his seat and passed from one cardinal to another telling them that his Majesty the Emperor would never consent to the election of Paolucci. Althann's announcement was evidently a surprise and dis-

The Month, October, I903.

'Die kaiserliche Exclusive im Konklave Innozenz XIII, Sitzungsberichte der kaiserlichen Academie der Wissenschaften in Wien, 170, B. 5. 


\section{The College of Cardinals and the Veto}

appointment to the cardinals, especially as the ballots were being collected. Paolucci displayed remarkable patience and self-control; he said that he did not deserve the high office, nor did he either hope for it or aspire to it, but that he was ignorant of any injury that he might have done his Majesty the Emperor in return for which he should suffer such mortification. On the following day, Cardinal Althann went to the heads of orders and to the chamberlain, and told them that the Emperor explicitly and formally excluded Cardinal Paolucci, and he besought them that they would spread the news among the other cardinals lest any should cast their votes for Paolucci and compel him publicly and openly and in the middle of the chapel to proclaim the Exclusion. Again, when shortly afterwards Paolucci received four votes, Althann reminded the voters of the Imperial Exclusion. Later, while he was acting as a scrutator and saw that Paolucci was still lacking three or four of the necessary number, and before the full number was taken from the boxes and counted, Althann stood in the middle of the chapel and said that the votes were not to be given to Paolucci. For some time the Paolucci party protested by casting blank ballots. The cardinals as a whole considered the conduct of Althann inexpectata et insolita. Emotionally, it caused them the greatest grief. One of them, Rohan, insisted that it was ultra vires, because it violated the liberty of the Sacred College and limited the freedom of election. Thus far Barberini.

Nevertheless, Paolucci was not elected,-a fact which correctly interprets the mind of the college. The cardinals de facto (whatever their de jure opinion may have been) yielded to the Emperor. Wahrmund, supporting with the information contained in the Barberini Diary his early theory that the conclave of I72I marked the first appearance of the formal Veto, is convinced that the eighteenth and nineteenth century types of Exclusion find their first instance in that of 1721. Other scholars disagree with him, 


\section{I64 The College of Cardinals and the Veto}

thinking that the conclaves at the end of the seventeenth century are the turning point. But none of them wrote in the light of the detailed information contained in Wahrmund's discovery. Heretofore states had informed the college that certain candidates were unacceptable. It remained for Althann, not only to do it in a very public manner and to reiterate the protest, but to stand in the middle of the chapel and insist upon its passage. Of even greater significance for this conclave as a departure from custom is the interference of Althann during the counting of the votes, an act, which, as his own diary says, brought the session to an end and made the cardinals leave the chapel in apparent disgust with the inevitable. ${ }^{x}$

When one pushes back into the seventeenth century one meets with another kind of royal interference and also with a most significant controversy as to its legality. Possibly the conduct of the kings of Spain and of Louis XIV will illustrate its character with sufficient clearness.

It must be remembered that during the first half of the seventeenth century the conclave policy was largely directed by nepotistic factions. The recent pope would have elevated cardinals who in many cases were not only relatives but men of his own point of view. These devotees, therefore, were likely to form a solid phalanx in the coming election. They were also inclined to bargain with the jealous states. Innocent XII's Bull of 1693, Romanum decet Pontificem, seems to have put an end to such a contingency. His example as well as his legislation made for its abandonment. It must also be recalled that the Thirty Years' War was raging until the middle of the century, and that the states looked upon the papal alliance or sympathy as a powerful ally.

The conclaves of 1644 and 1655 are typical of the changing mood of the times. The first was governed entirely by

"Wahrmund in Sitzungsberichte der kaiserlichen Academie der Wissenschaften, I70, B. 5, p. 12, n. I. 


\section{The College of Cardinals and the Veto 165}

the nepotists in league with princes; the second by the alliance of cardinals and princes apart from nepotism. In both Spain was pitted against France; in both France finally yielded. It is impossible to decide in which conclave the interference of the state was the more conspicuous.

In the conclave of 1644 one of the cardinal-nephews, Francesco Barberini, had two candidates in reserve, so that in case of the exclusion of either his interests might prevail. The first, Sacchetti, was a strong favorite of the French King; the second, Pamphili, was equally supported by Spain. Spain stood firm that Sacchetti should not be elected, and in spite of the continued support of his adherents, it would not yield. France, however, was less stubborn, and on the announcement that the French objection to Pamphili had been withdrawn, the latter was elected as Innocent $X$. It is said by some that Barberini lied in declaring the assent of France; others say that the French Ambassador was bought. In any case we have a remarkable example of diplomacy in which the states seem to have exercised a determining power. We have also, as Lucius Lector has said, an opportunity to call upon the preventive legislation of Gregory XV if that legislation was intended to deny any right to princes. The conclave is also noteworthy in that it recognized the nation's right to interfere in the case of one candidate only, a precedent which has been strictly observed by the nations since that day.

In the conclave of 1655 the effort to suppress nepotism had been partially successful. But nothing had been done to restrain the states. Again Sacchetti was put forward as the candidate of the French party. But Spain resisted not only on the ground of his being persona non grata, but on the already well-established precedent that semel exclusus entailed semper exclusus, the double exclusion of Baronius having fixed the unwritten law. ${ }^{x}$ The justification of the

I This principle again has been accepted from that time to this by cardinals and kings. 


\section{The College of Cardinals and the Veto}

custom was not accomplished without difficulty, for the intransigeant party or flying squadron, as they were called, cast thirty-three votes twice daily for two months for Sacchetti, and all the other ballots bore the word "Nemini." The deadlock became so hopeless that it gave rise to another name for Sacchetti, Cardinal Thirty-Three, and to the somewhat grimly humorous suggestion that the papal tiara would be offered to "Nemini." The episode was brought to an end by the Spanish Ambassador, who gave the public Exclusion through the window. Again France was known to object to the second candidate, Chigi, and again a withdrawal of its virtual Exclusion was obtained.

The salient features of these conclaves are, therefore, nepotism as a factor in election, an alliance between parties within the conclave and those without, a waning influence of the nepotists and a waxing power of conclave factions in association with the princes. The radical difference between these and the conclave of I72I lies in the exclusion being assumed as a working policy from the beginning of the election rather than in its public announcement by a member of the conclave during the process of voting; again, in its being publicly pronounced by a lay ambassador instead of by an empowered cardinal.

A most significant pamphlet war took place at this time, which, to the mind of Wahrmund, ${ }^{1}$ throws light upon the contemporary opinion in regard to secular interference in papal elections. The problem raised by the first candidacy of Sacchetti was its occasion. The confessor of the college, Valentini, was asked if the conclave might resist the veto imposed by so powerful a state as Spain and was told that it could not. Immediately Cardinal Albizzi published a treatise in which he attacked the right of states to interfere except in a manner of friendly advice. Not wishing to stand alone, Albizzi, a supporter of Valentini, appealed to the scholarly Cardinal Lugo, expecting that in union they might

I Wahrmund, Beiträge sur Geschichte des Exclusionsrechtes, 1890. 


\section{The College of Cardinals and the Veto}

achieve the freedom of the college. Much to his surprise, however, Lugo appeared as the doughty defender of the opposition. He said that the object of election should always be kept in mind; that the elevation of Sacchetti, a confederate of Mazarin, would not minister to the peace and unity of the Church. He acknowledged that there was no canonical warrant for the interference of the state in election; neither was there any canonical reason why the state should not advise and warn. The interests of the state were involved in an election of a pope, therefore the will of the state should be a factor in the final appointment.

These two documents were merely the first of many. They reveal the sensitiveness of the cardinals to the possible dangers of the situation; they also bring out in clear relief the cardinals' consciousness that an election of a pope was of international political significance. As Lector reminds us, however, not one of the pamphleteers dreamed that he was discussing the merits of a formal Exclusion. Technically speaking, there was no formal Exclusion at the time, as the withdrawals of Louis XIV indicate, and as his definite declaration that he had no power to exclude anyone affirms. The states of a later time acted as if they had an indisputable and final right. They do not discuss the problem; they do not present their reasons. Their representatives pronounce the Veto, and there the prospects of a certain candidate end.

During the middle of the seventeenth century, within the experience of the two conclaves considered and within the doctrines of the pamphleteers, two states have been of particular prominence: France and Spain. It would be fruitless to ask why these states and Austria alone have claimed the right of interference in modern times and have been allowed it. It is comparatively easy to see why England neither asks for nor is given the privilege. It is not so clear that Portugal and Naples should be excluded from positive action. There has been an attempt to prove that Portugal had the right during the first half of the eighteenth century, 


\section{I68 The College of Cardinals and the Veto}

and the motive is correct, for Portugal was then a world influence, as its initiative in the controversy over the Jesuits abundantly proves. But Ferdinand of Naples confessed that his throne had no right whatever. He told his cardinal in the conclave of 1823 that France, Spain, and Austria alone had the right of esclusiva espressa, but that he must, among his friends and adherents, make vigorous use of the esclusiva tacita. Being ignorant of the reason we must be content with the fact that they alone are possessed of the right.

The title, however, may lie in the double character of these states as heirs of the genius of empire, and therefore of the Emperor's prerogative, and as politico-catholic powers in modern times.

State interference in certain of the papal elections of the sixteenth century bears the mark of imperial concern, and the attitude of the cardinals is an eloquent recognition of the relationship.

Although the empire had largely disintegrated in the days of Philip II there can be little question that Philip himself represented both the Imperial or Hapsburg influence and that of the Church. His despotic conduct toward popes and cardinals as well as his similar association with the states of Europe reveals the intimate connection. Singularly, however, his interference takes the form of Inclusion rather than of Exclusion - a kind of pressure not uncommon to this and a later time, and not unacceptable to the cardinals. The cardinals of the conclave of I559 deliberately asked the will of France and Spain. France replied that it wanted Gonzaga of Mantua. Philip II replied in another vein:

If Carpi does not suit d'Este, and if Gonzaga and Puteo do not satisfy Farnese, that is no reason for thinking them unworthy. If Tournon is French and Pacheco Spanish, is that sufficient ground upon which the Italians should reject them? Is not the Catholic Church œcumenical? If Morone has committed a few sins, why has he been absolved? If Cesi is a likely person, should his relatives militate against his chances? 
Philip had his way. The cardinal favored by France was not elected. Furthermore his somewhat sarcastic response to the cardinals suggests his mastery of the situation.

Philip's relation to the conclave of 1559 is typical of his conduct and that of the cardinals throughout his reign. Although he was not invariably successful, as for example in the election of Urban VIII, he generally prevailed. $\mathrm{He}$ presented a list of three to the college of 1572 ; his ambassador had the final word in that of 1585 ; he presented another list of seven to the college of 1591 , thereby excluding about fifty cardinals. In brief, ${ }^{\mathrm{I}}$ he had the actual appointment of six popes, and, although there is no instance of an Exclusion in the latter sense of the word, there is a determining influence formed of his personal power coupled with that of his party within the college. His hold on the cardinals is seen in the fact that forty of the members of the conclave of 1605 were dependent upon Spanish bounty.

The thirteen-year pontificate of Clement VIII gave an opportunity to review the situation. It even forced Philip to appoint a commission to report upon it. Upon its failure to act before his death his son appointed another commission which came to the conclusion that the King of Spain might legitimately exercise an influence upon the election of a pope in order that his own interests might be safeguarded; that he might have recourse to either the Inclusion or Exclusion to prevent an unworthy man from ascending the papal throne; that he is permitted to dispense his favors to this very end, provided he does not form any contract that would limit the electoral freedom of his beneficiaries. Nothing could indicate more clearly the composition of the commission. It was Spanish. Nothing could make more apparent the need of a complete revision of the rules governing papal elections. And this was attempted by Gregory $\mathrm{XV}$ who ascended the papal chair in I621. His rules, whether rightly or wrongly interpreted, are dominant at the present day.

I Lucius Lector, Le Conclave, p. 535. 


\section{I70 The College of Cardinals and the Veto}

They found their occasion and their cause in the close interrelationship of Spain and the Papacy during the latter half of the sixteenth century.

Philip, however, merely confirmed the habit that he inherited. He had come by it honestly. Possibly it might be said that he made vicious use of a perfectly respectable custom. Possibly again he might have been the victim of that subtle change from a reputable imperial concern to a disreputable national interference-disreputable because the interests of Spain were being buttressed by the waning spirit of empire. Ferdinand of Austria had given Philip a very concrete example of dictatorial conduct in anticipating the death of a pontiff and the consequent election by definite instructions, dextere et modeste omnibus modis, to prevent the election of an enemy of the empire, and in forbidding the election of Cardinal Gonzaga of Mantua. His ambassador assured him that choice would fall upon "a most loyal pope." Charles V, of greater imperial significance than either Philip or Ferdinand, in the first formal letter addressed to a college, did not hesitate to urge the electing cardinals of 1534 to hold in mind "public tranquillity and the peace of Christendom." Charles may have been remembering his greater namesake when he justified his interference by referring to his character as protector of the Church. He may possibly have been aware that unity depended upon him, for the Protestant states had already taken their stand and the popes were little inclined to compromise. Charles hoped that a council guided by the right people would accomplish the reunion of Germanic Christendom. The popes of the council were more concerned in the integrity of tradition than in that of empire. Hence the watchfulness of Charles. Hence also the remarkable independence of Caraffa. The leader of the imperial party might warn Caraffa that he must abandon all hope of becoming pope because he was not in favor with the Emperor, but the ardent reformer might reply: "So much the better, if God will my election I shall be under obligation 


\section{The College of Cardinals and the Veto}

to no man." Charles met with opposition and with occasional defeat. But he was more the master than the slave of the relationship of Church and State.

It is unnecessary to examine the days preceding Charles and to search for the motives that regulated the election of Renaissance popes. Suffice it to say that the futile attempt of the reforming councils to reduce the college to a representative constitution had been followed in general by an era of feuds among the Italian states and of jealous rivalries among the Italian families. These were frequently the determining factors in election.

Reviewing, therefore, the four episodes, one can see that each presents characteristics peculiar to itself. Within the sixteenth century emperors and kings make their wishes clearly known; they present their lists of candidates. In the middle of the seventeenth century secular rulers have their parties within the college, and their accredited ambassadors in the immediate neighborhood; they are both opposed and supported by the canon lawyers of the day. At the opening of the eighteenth century there is a transition from a forceful influence to a dominating right; no moment short of actual election is too late for an empowered cardinal to pronounce the Veto. At the dawning of the twentieth century a pope publishes a constitution in which the Veto is expressly forbidden.

The next conclave alone, provided the Veto is attempted, can determine whether the Exclusion is a matter of history or whether it belongs to the fiber of a Church of imperial significance. Pius $\mathrm{X}$ has taken sides in the controversy that has long been waged between those who, like Sägmuller, hold that the Veto has always been a despotic interference, and those who, like Wahrmund, regard it in the light of unwritten law. In referring to papal legislation of the past, beginning with Pius IV and ending with Pius IX, the present pope (Pius $\mathrm{X}$ ) thinks that there has been a threecentury opposition to the Exclusion, while those who are of 


\section{The College of Cardinals and the Veto}

another mind infer that constitutions and bulls have been too general in their phraseology to affect such a concrete matter as this. I venture to suggest that Herbert Thurston is wrong in imagining that the Exclusion and the temporal power of the papacy are in some way of inseparable significance, and therefore that the days of the Veto are necessarily at an end. I should say rather that the Exclusion and the political connotation of an international Church are the inseparable elements, and that the Exclusion or the possibility thereof may be not only permissible for the states concerned but wholesome for the Church involved. And I can not help feeling that such is the instinct of Romanism to-day. The Civilta Cattolica declared the Veto dead when it did not appear in the election of Leo XIII. Thurston criticizes Austria for employing it in the conclave of 1903 . Both believe that its time has come. But they do not remember that France and Austria threatened to censor the decrees of the land-poor church of 1870; they have forgotten that Bismarck $^{\mathrm{I}}$ may have been blundering at the truth when he suggested in 1872 some kind of international agreement in the recognition of a pope; they are oblivious to the present relationship between Church and State in Italy, which is one of living protest against the withdrawal of temporal power and of refusal to participate in the new civil régime.

\section{BIBLIOGRAPHY}

Mémoires du Cardinal Consalvi, ed. J. Crétineau-Joly, Paris, I866 (Conclave of 1799); FrIEdERICH GIESE, "Die geltenden Papstwahlgesetze," Kleine Texte für Vorlesungen und Übungen, herausgegeben von Hans Lietzmann, No. 85, Bonn, 1912; P. Herre, Papsttum und Papstwahl im Zeitalter Phillips II, Leipzig, I907; LuCIUs LeCTOR, Le Conclave, Paris, I894 (chapters 12, 13, 14); Françors-Désiré, Cardinal Mathieu, les derniers Jours de Léon XIII et le Conclave de 1903, Paris, 1904; FREDRIK NIELSEN, History of the Papacy in the XIXth Century,

I Wurm, Die Papstwahl, p. 85. 


\section{The College of Cardinals and the Veto $\mathbf{1 7 3}$}

New York, 1906 (Conclaves of I799, I829, 1830); J. B. SÄGMŬller, Die Papstwahlen und die Staaten von 1447 bis 1555, Tübingen, 189o; SÄGMÜLler, Die Papstwahlbullen und das staatliche Recht der Exclusive, Tübingen, I892; HeRBERT ThURSTON, "Intervention of the State in Papal Elections," The Month, 1903; L. WAHRMUND, Ausschliessungsrecht der katholischen Staaten, Vienna, I888; WAHRMUND, "Die kaiserliche Exclusive im Konklave Innozenz XIII," Sitzungsberichte der kaiserlichen Academie der Wissenschaften in Wien, 170, B. 5; Nicholas Patrick, Cardinal Wiseman, Recollections of the Last Four Popes, London, no date. For further bibliography see Encyclopeedia Britannica, and Catholic Encyclopedia, v., 678. 